Journal of Health Policy and Management (2018), 3(2): 108-113

https://doi.org/10.26911/thejhpm.2018.03.02.07

\title{
Implementation of Community Mental Health Service in Malang, East Java
}

\author{
Zuhrotun Ulya, Adi Sulistyono, Widodo T. Novianto
}

Master Program in Law, Universitas Sebelas Maret

\begin{abstract}
Background: The culture of mental-health care in Indonesia relies heavily on backward pseudo-science rooted in dated spiritual traditions. In Indonesia, some people with mental disorder was shackled in sheds or backyards for years on end, which is known as pasung. Based on report, 1 in 7 mental disorder patients were at risk of pasung. The success of mental health service program need a collaboration from community as preventive and promotive besides curative component. This study aimed to analyze the legal system working based on legal, substance, and law's culture in Wonorejo, Malang District, East Java.

Subjects and Method: This was a qualitative study (descriptive non-doctrinal legal research) conducted in Wonorejo, Malang, East Java. Nine informants consisting of psychiatrist, general doctor, nurse, caregiver, social worker, public health officer, and village leader was selected for this study by purposive sampling. Data collected by interview, observation and documentary review. Data were analyzed by data reduction, presentation, and verification.

Results: Integration of human resources is needed as a driver of the legal structure and there was urgency to add more resources (human, technology, fund). The constraint of this program is the limited number of workers (doctor, nurse, social worker) and limited distribution and kind of psychiatric drugs. Communication as a modality of legal substance has done well between social worker, caregiver, public health services, mental health hospital dan village). Community acceptance be legal culture was completely done by various educational programs, advocacy, and socialization. There was good coordination and acceptance between internal and external legal culture. The legal system has done well and leads to optimal community mental services.

Conclusion: Analyzing of legal system working in community mental health services from structure, substance and legal culture in Wonorejo, Malang District, East Java has shown integration, effectiveness and acceptance from their community. Implication of this study that are needed policies to increase resources and fulfill of psychiatric drug distribution that was need by the patient.
\end{abstract}

Keywords: community, mental health, legal system

Correspondence:

Zuhrotun Ulya. Masters Program in Law, Universitas Sebelas Maret, Jl. Ir. Sutami 36 A, Surakarta 57126, Central Java. Email: psychiatry.law12@gmail.com. Mobile: o82232839048.

\section{BACKGROUND}

Community mental health services are community-based mental health services, which all potential in the community is actively involved. The paradigm of community mental health services involves the concept of treating mental health problems in promotive, preventive, curative and rehabilitative aspects. The approach to treat mental disorders shifts from clinical- individual to productive-social in accordance with development of community mental health concept. Community mental health services can be provided by trained personnel, such as mental health worker, caregiver, nurses, teacher and related sectors. Increasing of mental disorders in community need more attention. It is undeniable that incidence of mental disorders can occur in various conditions, 
not limited ti the severity of stressor, heredity, overload, etc.

Based on Riset Kesehatan Dasar 2013, mental disorder cases up to 1.7 per mil and 1 in 7 mental disorder patients had a risk of pasung (Idaiani, 2013). This problem become a burden not only for family, but also community and Government. Curative aspect cannot solve all community mental health problem. Establishment and sustainability of community mental health services is deemed necessary and urgent to be carried out because of increasing mental disorder cases in various regions. Government has published a policy about implementation community mental health services (Ministry of Health Act No. 406/ 2009). Psychiatric Department Saiful Anwar Hospital said, throughout 2010-2011 there were 3-5 cases of suicide attempts and 7 new cases of mental disorder per month. Also 179 per 1000 people experiencing non-psychotic disorders and 3 per 1000 people with psychotic disorders. In some cases mental disorder patients came with emergency psychiatric condition, $80 \%$ of them was relapse or recurrence cases (Ulya, 2012). Cases of mental disorders in Malang District have not received great attention until the Governor of East Java declared Jawa Timur Bebas Pasung 2017 program (BAPPEDA Jatim, 2014).

The declaration was followed up with efforts of coordination mental health services in each region, start with break of pasung include of Malang District. In 2016, there were 99 cases of pasung in Malang District which 86 of them were released. Especially at Wonorejo village, there were 33 mental disorder patient which 6 patient on pasung. The tendency of increasing mental disorders cases in community has an impact on productivity and quality of life. The solution for this condition, synergy was needed between health care providers, relevant sector and community. Clinical individual treatment from curative perspective cannot solve community problem. Community active role was needed to play a role in handling mental disorders.

In order to empower environment in mental health care to be independent in solving mental health problem and their financing, be responsive and able to handle as well healthy living behavior, it is necessary to form and establish community mental health services. Collaboration of Dr. Radjiman Wediodiningrat Mental hospital with Public Health Center Ardimulyo, Dinas Sosial and Dinas Kesehatan Malang District make Posyandu Jiwa to form mental health communities which located in Wonorejo since 2016. This study aimed to analyze implementation of communities mental helath services through the legal system working based on structure, substance and legal culture in Wonorejo, Malang, East Java.

\begin{tabular}{l}
\hline SUBJECTS AND METHOD \\
\hline 1. Study Design \\
This was a qualitative study and descriptive \\
non-doctrinal legal research. The study was \\
conducted at in Wonorejo, Malang, East \\
Java. This study aimed to analyze the legal \\
system working based on legal, substance, \\
and law's culture using Lawrence M. \\
Friedman theory.
\end{tabular}

\section{Study Informants}

Informants of study from community mental health team who chosen by their competencies and acknowledges about community mental health problems and Government policy. The informants include of 2 caregiver, 2 social worker, 1 public health officer, 1 village leader, 1 general doctor, 1 nurse and 1 psychiatrist.

\section{Data Collection and Data Analysis}

The data collected by interview, observation, and document review. The data were 
Journal of Health Policy and Management (2018), 3(2): 108-113

https://doi.org/10.26911/thejhpm.2018.03.02.07

analyzed by data reduction, presentation, and verification.

$\frac{\text { RESULTS }}{\text { 1. Legal Structure }}$

Legal structure of community mental health services in Wonorejo involving village leader, non-communicable unit of Malang Health Office, social service of Malang District, Dr. Radjiman Wediodiningrat Mental Health Hospital, Ardimulyo Public Health Center, social worker, and caregiver. In the beginning of the community mental health program realization was preceded by break chain of pasung. Social service of Malang District collaborates with mental health hospital monitoring all mental health disorder patients in this area. This program was constrained by the number of field implementers because limited of social worker (8 people for 33 sub-districts), few caregivers. At that time, Ardimulyo Public Health Center has less personnel resources (only 1 doctor and 2 nurses who handle many programs). Another problem is limited stock of drug provided by health office. The proposed type of drug (especially antipsychotic) has been sought by mental health hospital through monitoring of condition mental disorder patient and type of medication needed. However, there were a number of drug which stored in large amounts which not suitable with the patients condition.

\section{Legal Substance}

Legal substance is another element that is composed by regulations and provision regarding how the institution must behave. Related with implementation of community mental health service program, communication has been established between various components of legal structure. It means, legal substance was fulfilled by established system. Communication and collaboration between structure was performed by recommendation from social service to give full fund accessible in hospital especially for mental health disorder patient with pasung. This finance claim beyond national insurance health which funded by East Java provincial government. Problem raised from administrative aspect. Mental health disorder patient often do not have identification and family cards. This problem will disturb and constrained by the provision of administrative problem before finally being able to got treatment at public health center or mental health hospital. This problem often dealt with and assisted by the management team of public health center and caregiver in community.

3. Legal Culture

External legal culture exists in general population, which initially found many rejections especially from pasung cases. This rejection as response of family difficulties to handle mental disorder patient. Some of the reasons such as stigma from patient in community like disgrace, being cursed, sign lack of faith, attacked by demon, being trash, unworthy, have no chance of life and have no future. Stigma leads to discrimination of patient's rights in various matters including pasung. Pasung can occur due to trauma in family because of violence acts committed by patient, they refuse patient back to in family after treatment, concerns about another risk will be faced if the patient around them, and burden of economic. When the efforts of community mental services was working, internal legal culture is able to invite their community to care and bring empathy. Education, communication and information via social media, psychosocial rehabilitation and telepsychiatry become a effective tools to attract external legal culture component. Through advocacy and coaching process, there was no pasung in Wonorejo, rehabilitation still exist and maintain- 
ed well, and there is more caregiver was joined. The result of rehabilitation was increasing the patients productivity, and now Wonorejo was acknowledged with sponge sandals makers which all product was working by mental health disorder patients.

\section{Legal Structure}

\section{DISCUSSION}

The legal structure becomes the institutional framework or body of a system. This need collaboration from many sector related to build community mental health services as an element of the structure which drive in society. The structural system will move dynamically which influenced by several factors. In this study, several factors that influence the implementation of legal structure such as limited resources of social worker, power, medicine and mental health personnel in village. Integration of human resources, especially health workers who are directed to the mental health program requires an assessment at level of recruitment, guidance and supervision such as human resources for health workers in general. Even though the sources for implementing the policy are sufficient and know what and how to do, the implementation can still not be effective because there are problem in the existing bureaucratic structure. In Wonorejo, nurses and health workers are assisted by the collaboration of social workers and caregivers in community. Psychosocial rehabilitation and early detection of mental disorders as well as mental health taught in community, it will be come magnet to pull enthusiasm. This requires regular monitoring so the system can still work. Limited drug problem in Posyandu Jiwa and Public Health Center can be dealt with another examination of conditions so the procurement of drugs can be adjusted. If this condition is inevitable, the referral system to mental health hospital must be sought.

\section{Legal Substance}

Community mental health services in Wonorejo has established by cooperation between structures. No problem from funding of medical expenses especially pasung cases because was managed by East Java Provincial beyond national health insurance. The government try to alleviate the financing problem which is often became chief complaint from patient's families. Integrated community mental health services with handling of pasung cases become national programs that demands an urgent settlement in each region. These efforts are accompanied by policy products that are directly correlated with the effectiveness of pasung regulation. This is influenced by components of legal structure that are able to carry out and respond actively to the leaders instructions, have commitments to implement the policy, the existence of demands and interventions that lead to efforts to solve the problem in community. Malang district which interpreted by their social workers, caregivers and health team personnel still try to trace and find new cases of mental disorders, follow free pasung programs and monitor after curative care. Mental health problem is not only mental hospital problem, but also all health center units and related sector. Communication in Wonorejo as legal substance well integrated.

\section{Legal Culture}

Legal culture is an element of social attitudes and values. A policy become success and work well in community when the legal culture (external and internal) is acceptance and can change behavior as an impact. The attitude of implementator as the main actor in context of internal culture will deal wth external culture. In the beginning period of community mental 
health services policy was started, a few families refused this program. This is as variant of external legal culture respond. When mental health programs have no support from regional leader, government, and strong policy have no great structure, the system will never be walked and be blind. Mental health program tends to be curative only and will end in referral system direction. At present, through advocacy and sufficient publication, pasung cases was to be solved, mental health disorder patient was able to treat adequate in public health center or hospital. External legal culture in Wonorejo was accepting community mental health services policy as their community programs. Education, early detection and prevention of mental health disorder become large portion to be implemented in this area. Another homework for this community is increasing the portion of psychosocial rehabilitation, facilitation of national health insurance, monitoring patients symptoms and drug compliance, development of day care services and productivity from patients. The activity was also directed to community, housewives, youth groups and caregivers.

Community mental health services policy requires many resources from multi sector. It need of extension and large ideas that can bring life to the community. If this is not fulfilled, the program tends to be stagnant. Psychosocial aspects have begun to be turned on and part of rehabilitation because it relates with patient insight, medication adherence, willingness to take psychotherapy and post curative development. The development of community-based mental service integration, starting with policy coordination, multi sector implementers and active role from community is the key of great implementation. Analyzing of legal system working in community mental health services from legal structure, legal substance and legal culture in Wonorejo, Malang District, East Java has shown integration, effectiveness and acceptance from the community. Implications of this study that are needed policies to increase resources and fulill of psychiatric drug distribution that was need by mental health disorder patient.

\section{REFERENCE \\ BAPPEDA Jatim (2014). Jatim Bebas Pasung Dideklarasikan di Ponorogo. Retrieved from http://bappeda.jatim- prov.go.id/2014/06/20/jatim-bebas- pasung-dideklarasikan-di-ponorogo/ \\ Basco M, Bostic J, Davies D (2013). Methods to Improve Diagnostic Accu- racy in a Community Health Setting. American Journal of Psychiatry, 1-12. \\ Boscarino J (2015). Community Disasters, Psychological Trauma, and Crisis Intervention. International Journal Emergency Mental Health, 369-371.}

Boudreaux E, McCabe B (2014). Emergency Psychiatry: Critical Incident Stress Management, Intervention and Effectiveness. Psychiatric Services, 1-8.

Bowers L (2006). Psychiatric Intensive Care Units: a Literature Review. London: City University E1 2EA.

Caplan G (2013). An Approach to Community Mental Health. London: Tavistock Institute.

Chanmugam A, Triplett P, Kelen G (2013). Emergency Psychiatry. New York: Cambridge University Press.

Collins P, Patel V, Joestl S, March D, Insel T (2011). Grand Challenges in Global Mental Health. Nature Reviews, 7-12.

Ena E (2011). Emergency Nurses. Retrieved from Emergency Nurses Association: http://www.ena.org/IENR/Documen ts/ENAEVSSReportAugust2010.pdf

Idaiani S (2013). Riset Kesehatan Dasar 2013. Jakarta: Badan Penelitian dan 
Pengembangan Kesehatan Kementerian Kesehatan Republik Indonesia. Jorm A (2012). Mental Health Literacy: Empowering the Community to Take Action for Better Mental Health. American Psychologist, 21-29.

Knoll JL (2014). The Psychiatric ER Survival Guide. Upstate Medical University. New York: University of New York.
Ministry of Health Act No. 406/ 2009 abou Community Mental Health Services Guideline.

Ministry of Health Regulation No. 54/ 2017 about Pasung on Mental Disorder Patients Treatment.

Ulya $Z$ (2012). Data Pasien Divisi Psikiatri RSSA 2010-2011. Malang: Divisi Psikiatri RSSA Malang. 